UDC $576.7+577.21$

\title{
Human cultured cells are capable to incorporate isolated plant mitochondria loaded with exogenous DNA
}

\author{
E. S. Klimenko, I. A. Zaporozhchenko', V. A. Mileyko', E. S. Morozkin', \\ M. V. Koulintchenko, P. P. Laktionov ${ }^{1}$, Yu. M . Konstantinov
}

Siberian Institute of Plant Physiology and Biochemistry, Siberian Branch of the Russian Academy of Sciences 132, Lermontova Str., Irkutsk, Russian Federation, 664033

${ }^{1}$ Novosibirsk Institute of Chemical Biology and Fundamental Medicine, Siberian Branch of the Russian Academy of Sciences 8, Akademika Lavrentieva Ave., Novosibirsk, Russian Federation, 630090

katia.klimenko@gmail.com yukon@sifibr.irk.ru

\begin{abstract}
Aim. To investigate the possibility of human cultured cells to incorporate isolated mitochondria together with exogenous DNA introduced into organelles. Methods. Two approaches were used for this purpose, fluorescent labelling of mitochondria and/or DNA with subsequent analysis of the cells subjected to incubation by microscopy or by quantitative PCR. Results. We have shown that human cultured cells lines, HeLa and HUVEC, are capable to uptake isolated plant mitochondria and that this process depends on the incubation time and concentration of organelles present in medium. The incorporated mitochondria can serve as vehicles to deliver exogenous DNA into human cells, this DNA is then distributed in different cell compartments. Conclusions. These results are preliminary and need further investigations, including testing the possibility of human cells to incorporate the mitochondria of human or animal origin and creating genetic construction which could provide certain selectivity or stability of the transferred exogenous DNA upon cell uptake of the mitochondria as vectors.
\end{abstract}

Keywords: human cultured cells, DNA-loaded mitochondria, xenotransplantation.

Introduction. The reason of high distribution of so-called human «mitochondrial diseases» is the presence of numerous structural and functional gene disturbances in the mitochondrial genome. To cure these diseases, some new molecular and cellular technological approaches are necessary.

As it was shown previously, plant, yeast and mammalian mitochondria possess a mechanism of natural competence for DNA uptake [1-4]. Those organelles might be used as potential vehicles for cell transformation in vivo in order to study mechanisms of horizontal gene transfer and to develop new biomedical technological approaches for gene therapy of human mitochondrial diseases.

Material and methods. Mitochondria were isolated from potato tubers (Solanum tuberosum), and the

(C) Institute of Molecular Biology and Genetics, NAS of Ukraine, 2012 import conditions were performed as it was previously described $[1,5]$.

MitoTracker Orange CMTMRos $(500 \mathrm{nM})$ and Hoechst $33342(0.1 \mu \mathrm{g} / \mathrm{ml})$ were used respectively to label fluorescently the isolated potato mitochondria and the mitochondrial DNA.

To investigate the transport of mitochondria into eukaryotic cells, we used cultured cell lines of human adenocarcinoma (HeLa), primary fibroblasts (GF) and human umbilical vein cells (HUVEC). Cells were cultivated in IM medium, containing $10 \% \mathrm{FBS}$ and antibiotics, at $37{ }^{\circ} \mathrm{C}$ and $5 \% \mathrm{CO}_{2}$. Cells were incubated with mitochondria in growth medium without serum for different periods of time, then washed twice in the same medium and additionally incubated in IM with $10 \%$ FBS.

To estimate the efficiency of mitochondrial incorporation, cell probes were analysed by live-cell imaging using fluorescent microscopy with the help of Axio- 
Nucleotide sequences of primers and fluorescent probe

\begin{tabular}{|c|c|c|}
\hline Gene & & Nucleotide sequence \\
\hline \multirow[t]{3}{*}{$\cos 2$} & Reverse & 5'-AGCCTGCAATGTCCGATAAC-3' \\
\hline & Forward & 5'-ACCATTCCGAAGGTTACTG-3' \\
\hline & Probe & FAM 5'-TGGTATACAACTTTGGACCTAACAGCCGGC-3' FQ \\
\hline \multirow[t]{3}{*}{$g f p$} & Reverse & 5'-CGGGGCATGGCACTCTTGA-3' \\
\hline & Forward & 5'- CTGTTCCTTGGCCACACT-3' \\
\hline & Probe & Сy5 5'-TGTTCAATGCTTTTCAAGATACCCAGA-3' BHQ2 \\
\hline \multirow[t]{3}{*}{$\beta$-Actin } & Reverse & 5'-AGACAAAACACAGAAAAAGAGC-3' \\
\hline & Forward & 5'- CGTTTTCCGTAGGACTC-3' \\
\hline & Probe & TAMRA 5'-TCTGCAGGTTCTAATTTGCTTTTTCCCA-3' BHQ2 \\
\hline
\end{tabular}

vert 200M («Carl Zeiss», Germany) inverted microscopy device. Images obtained by Axiocam Mrm CCD camera were analysed with AxioVision 4.8 software. To estimate the efficiency of exogenous DNA uptake by mitochondria, we used the method of quantitative PCR. Oligonucleotide and fluorescent sequences used in PCR are listed in the Table 1.

Results and discussion. Effectiveness of mitochondrial uptake by cultured human cells depends on incubation time and mitochondrial concentration. To optimize the conditions for cultured human cells to uptake the fluorescently labelled mitochondria, we incubated the isolated potato mitochondria with HeLa cells or primary fibroblasts either for different periods of time (Fig. 1 , see inset) or at various organelle concentration in the incubation media (Fig. 2, see inset).

The concentration of mitochondrial suspension used for the incubation in the time course assay was $9 \mu \mathrm{g} / \mathrm{ml}$. The time of cell incubation with mitochondria is indicated (Fig. 1, see inset). The intracellular space is visualized by cell staining in $0.6 \mu \mathrm{M}$ Calcein-AM.

For both tested cell lines, we observed evident passing of the labeled mitochondria through the cell membranes, which was visualized by appearance of stained organelles in the cytosol. At all time points, nucleolus became also stained. The fluorescence intensity for MitoTracker dye achieved its maximum by an hour of incubation. Within time, the spectrum of fluorescent distribution altered with appearance of numerous granules.
We tested also the dependence of mitochondrial incorporation by cultured cells on organelle concentration present in the medium of incubation (Fig. 2, see inset). The optimal concentration of mitochondrial protein in incubation medium was $4.5 \mu \mathrm{g} / \mathrm{ml}$. The time of incubation was $60 \mathrm{~min}$.

Using of quantitative PCR to analyse isolated mitochondria uptake by cultured cells HeLa and HUVEC. To analyze the efficiency of mitochondrial translocation into cellular space, we tested also the possibility to use the method of quantitative PCR (TaqMan). Sequences of the mitochondrial gene cox 2 served as amplification primers (Table 1). In order to estimate which cellular compartment would become the preferred target for the mitochondrial DNA uptake, we tested both nuclear and membrane-cytosol fractions of the cellular extract, taken after cell incubation with organelles.

The results of quantitative PCR showed that in case of mitochondrial incubation with HeLa cells mitochondrial DNA goes mostly into the nuclear fraction, whereas in case of organelle incubation with HUVEC cells mitochondrial DNA is associated mainly with the membrane-cytosol fraction. In case of both cell lines, the efficiency of mitochondrial DNA incorporation into cells correlates directly with the mitochondrial concentration present in the incubation medium (Fig. 3).

By quantitative PCR, we analyzed the possibility of cultured cells to uptake exogenous DNA mediated by mitochondria transfer. 2,3PrGFP DNA-fragment (3 kb) 
Analysis of mitochondrial (cox2) and exogenous ( $g f p$ ) DNA presence in cell extracts after mitochondria uptake by HeLa cells

\begin{tabular}{|c|c|c|c|c|}
\hline \multirow{3}{*}{$\begin{array}{l}\text { Amount of purified potato mito- } \\
\text { chondria used per assay, } \mu \mathrm{g} / \mathrm{ml}\end{array}$} & \multicolumn{4}{|c|}{ Amount of DNA, ng/ 1000 cells } \\
\hline & \multicolumn{2}{|c|}{ Nuclear fraction } & \multicolumn{2}{|c|}{ Membrane-cytosolic fraction } \\
\hline & $\cos 2$ & $g f p$ & $\cos 2$ & $g f p$ \\
\hline Control cells $(0)$ & 0.98 & 4.96 & 20.91 & 1.79 \\
\hline 0.9 & 6.31 & 28.29 & 255.81 & 25.37 \\
\hline 9 & 4.29 & 26.04 & 781.06 & 41.56 \\
\hline \multicolumn{5}{|c|}{ Post-incubation time, $h$} \\
\hline $1.8-0$ & 1.67 & 12.29 & 104.59 & 14.95 \\
\hline $1.8-24$ & 4.13 & 11.73 & 53.18 & 9.53 \\
\hline $1,8-72$ & 6.24 & 14.91 & 152.78 & 1.76 \\
\hline
\end{tabular}

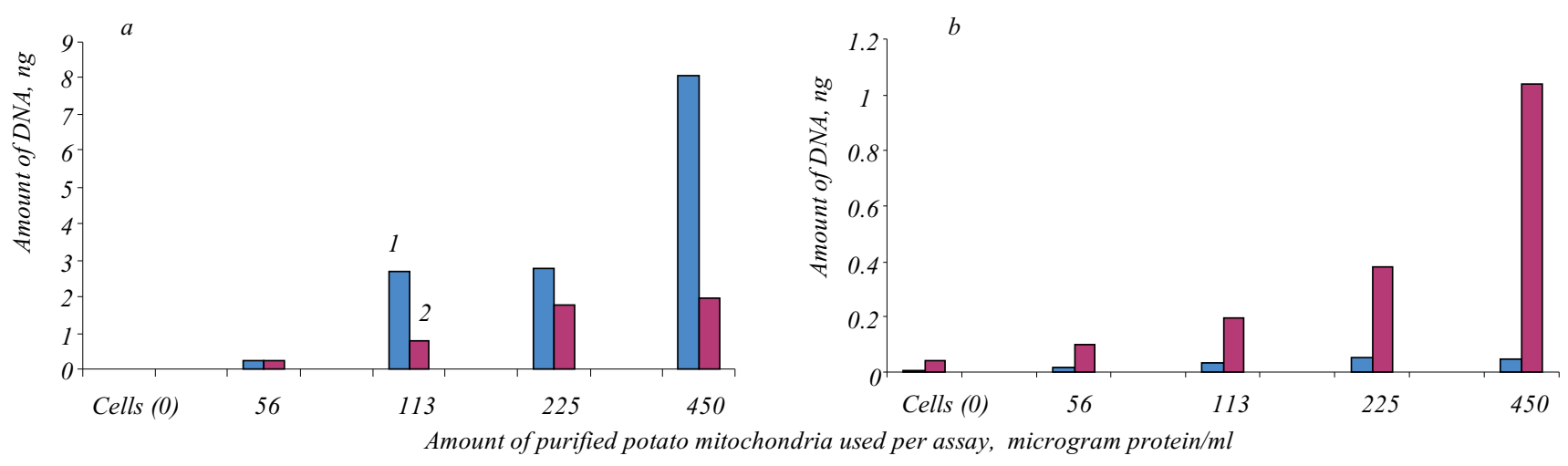

Fig. 3. Evaluation of mitochondrial uptake by HeLa $(a)$ and HUVEC $(b)$ cell cultures by quantitative PCR analysis of cox 2: $1-$ nuclear fraction; $2-$ membrane-cytosolic fraction

amplified from the 2,3PL/GFP plasmid was used for DNA import assay with mitochondria isolated from potato tubers. The import (DNA taken at $25 \mathrm{ng} / \mathrm{ml}$ concentration) was run in standard conditions (described in [1, 5]) for $40 \mathrm{~min}$, followed by DNase treatment. After import had been over, the mitochondria were incubated with HeLa cells, time of incubation was $2 \mathrm{~h}$. We analyzed the nuclear and membrane-cytosolic cell fractions both for DNA delivery and stability. In later case, after incubation with mitochondria, cells were washed and subjected to further incubation for indicated periods of time. The transfer of internal mitochondrial gene cox 2 to the membrane-cytosolic fraction was more effective when the mitochondria concentration in assay was increased.

Though the absolute amount of $g f p$ in this cell fraction was low, its relevant amount compared to control (background amplification) was at similar rate, 37-fold increasing for cox 2 and 23-fold - for $g f p$ (Table 2). The stability of the mitochondrial genetic material, both internal and exogenous, inside cells was however low and tended to degrade with time (Table 2).

Fluorescently labeled DNA (10 ng, by Hoechst 33258) was also used for import into isolated potato mitochondria with subsequent incubation of treated organelles with cultured cells. The protein concentration in these assays was $1.8 \mathrm{mg} / \mathrm{ml}$. As it was shown on Fig. 4 (see inset) some granular structures were observed in cytosol. Cells with nuclei stained by Hoechst 33342 were used as a control (Fig. 4, see inset).

As a control for specific mitochondrial incorporation, cells were incubated with the maximal amount $(100 \mathrm{ng})$ of the labelled DNA. The DNA delivery into cells mediated by mitochondria was 3 -fold greater com- 
pared to mock-treatment of cells with the fluorescent DNA alone (Fig. 4, see inset).

Conclusions. 1. Two methods could be used to analyse the efficiency of exogenous DNA uptake by cultured cells via mitochondrial delivery - fluorescent labelling of DNA and quantitative PCR.

2. Potato tuber mitochondria uptake by human cultured cells (HeLa, HUVEC, primary fibroblasts) was shown by fluorescent labelling and microscopy visualization. Fluorescently labelled mitochondria incorporation by human cultured cells depends on time of cell's incubation with mitochondria ( $1-2 \mathrm{~h}$ ) and on mitochondrial protein concentration $(1,8-9 \mu \mathrm{g} / \mathrm{ml})$.

Acknowledgements. This work was financially supported by the Siberian Branch of the Russian Academy of Sciences (Project 83) and Russian Fund for Basic Research 12-04-01400.

С. С. Клименко, І. А. Запорожченко, В. А. Мілейко, Є. С. Морозкін, М. В. Кулінченко, П. П. Лактіонов, Ю. М. Константинов

Клітини людини в культурі здатні поглинати рослинні мітохондрії, навантажені екзогенною ДНК

Резюме

Mema. Вивчення можливості поглинання клітинами ліній HeLa HUVEC ізольованих клітинних мітохондрій, попередньо навантажених чужорідною ДНК. Методи. Використано два методичних підходи: флуоресцентне мічення мітохондрій і/або мтдНК та кількісний ПЛР-аналіз ДНК інкубованих з мітохондріями клітин. Результати. Продемонстровано, щзо клітини людини ліній HeLa і HUVEC здатні поглинати ізольовані рослинні мітохондрії, i иеей процес залежить від часу інкубаиії $і$ кониентрації органел у середовищі. Мітохондріі, таким чином, можуть слугувати векторною системою для доставки чужсоріднӧ ДНК у клітини людини. ДНК, яка транспортується мітохондріями, розподіляється у різних клітинних компартментах. Висновки. Отримані результати мають попередній характер і дозволяють почати перевірку можливості поглинання клітинами людини мітохондрій тваринного походження (у тому числі мітохондрій людини) та створення генетичних конструкцій, які містять селективний ген $i$ забезпечують стабільне підтримання транспортованої мітохондріями екзогенної ДНК після поглинання їх клітинами.

Ключові слова: клітини людини в культурі, навантажені ДНК мітохондрії, ксенотрансплантація.
Е. С. Клименко, И. А. Запорожченко, В. А. Милейко, Е. С. Морозкин, М. В. Кулинченко, П. П. Лактионов, Ю. М. Константинов

Клетки человека в культуре способны поглощать нагруженные экзогенной ДНК растительные митохондрии

Резюме

Цель. Изучение возможности поглощчения клетками линий $\mathrm{HeLa}$ и НUVEC изолированных растительных митохондрий, предварительно нагруженных чужеродной ДНК. Методы. Использованы два методических подхода: флуоресчентное мечение митохондрий и/или мтДНК и количественный ПЦР-анализ ДНК инкубированных с митохондриями клеток. Результатыл. Продемонстрировано, что клетки человека линий HeLa и HUVEC способны поглощать изолированные растительные митохондрии, и этот процесс зависит от времени инкубации и конщентрации органелл в среде. Митохондрии, таким образом, могут служить векторной системой для доставки чужеродной ДНК в клетки человека. Транспортируемая митохондриями ДНК распределяется в различных клеточных компартментах. Выводы. Полученные результаты имеют предварительный характер и позволяют приступить к проверке возможности поглощения клетками человека митохондрий животного происхождения (в том числе митохондрий человека) и созданию генетических конструкиий, включающчих селективный ген и обеспечивающих стабильное поддержание транспортируемой митохондриями экзогенной ДНК после их поглощсения клетками.

Ключевые слова: клетки человека в культуре, нагруженные ДНК митохондрии, ксенотрансплантация.

\section{REFERENCES}

1. Koulintchenko M., Konstantinov Y., Dietrich A. Plant mitochondria actively import DNA via the permeability transition pore complex // EMBO J.-2003.-22, N 6.-P. 1245-1254.

2. Koulintchenko M., Temperley R. J., Mason P. A., Dietrich A., Lightowlers $R$. N. Natural competence of mammalian mitochondria allows the molecular investigation of mitochondrial gene expression // Hum. Mol. Genet.-2006.-15, N 1.-P. 143-154.

3. Ibrahim N., Handa H., Cosset A., Koulintchenko M., Konstantinov Yu., Lightowlers R. N., Dietrich A., Weber-Lofti F. DNA delivery to mitochondria: sequence specificity and energy enhancement // Pharm. Res.-2011.-28, N 11.-P. 2871-2882.

4. Mileshina D., Koulintchenko M., Konstantinov Y., Dietrich A. Transfection of plant mitochondria and in organello gene integration // Nucleic Acids Res.-2011.-39, N 17.-e115.

5. Klimenko E. S., Mileiko V. A., Morozkin E. S., Laktionov P. P., Konstantinov Yu. M. Study of DNA import and export in potato (Solanum tuberosum) mitochondria using quantitative PCR // Biochemistry (Mosc.). Suppl. Ser. A: Membrane and Cell Biology.-2011.-5, N 2.-P. 170-176. 